\title{
MANAJEMEN KOMPETENSI GURU NEGERI OLEH DINAS PENDIDIKAN KABUPATEN HALMAHERA TIMUR
}

\author{
Subhan Hayun $^{1}$ dan Rustam Hasim ${ }^{2}$ \\ ${ }^{1}$ Dosen PGSD, Universitas Pasifik Morotai \\ ${ }^{2}$ Dosen Prodi Pendidikan Pancasila dan Kewarganegaraan, FKIP Universitas Khairun, Jl. Bandara Baabullah Akehuda Ternate \\ Utara, 97728, Indonesia
}

Email: subhan.unipas@gmail.com

Diterima : 20-03-2018.

Direvisi : 30-03-2018

Dipublikasi : 05-04-2018

\begin{abstract}
This research was conducted to describe teachers' competence,the teachers' competence is one of the influence factor in education success, teacher's competence to cover: (1) pedagogic competence, (2) personal competence, (3) professional competence and (4) social competence.This research also studied the concepts of the teachers' competence, the factors influence in teacher's competence, the strategy of teachers' competence, and good management in teachers' competence. These researches were used qualitative approach. The data sources were consist of the head master, teacher and parents. The data were collected by observation, in-depth interview, and documentation. The obtained data were verified and analyzed through data verified, data reduction continued to take conclusion.The findings of the research are: (1) the distribution of teacher inthe environment of Provincial Office of Education, Youth and Sport of East Halmahera Regency is not good and, (2) The competences of teachers in the elementary schools must be upgraded to fulfill the standard of competence and (3) The development programs of teacher' competence in the elementaryschools were also not good.
\end{abstract}

Key Word: teachers' distribution, the developing teacher's competence, the systematization of management teacher's competence

\section{PENDAHULUAN}

Analisis kebutuhan tenaga guru yang berkompetensi sangat penting untuk menyukseskan pelaksanaan program otomi daerah. Untuk memayungi dan melindungi perangkat-perangkat daerah serta pelaksanaan rencana-rencana strategis dalam otonomi daerah, diperlukan suatu badan khusus yang sifatnya mengikat dan memiliki kewenangan untuk meningkatkan kebutuhan pendidikan masyarakat dalam hal ini adalah Dinas Pendidikan Pemuda dan Olahraga Kabupaten Halmahera Timur Provinsi Maluku Utara.

Kinerja mengajar guru sangatlah penting karena menentukan kualitas pembelajaran di sekolah.Kinerja mengajar guru merupakan faktor yang bisa mencerminkan sikap dan karakter seorang guru dalam melaksanakan tugas-tugasnya di sekolah. Kinerja mengajar guru merupakan nilai-nilai luhur yang perlu diinternalisasikan kedalam diri setiap guru agar ia bekerja dengan penuh gairah dalam memberikan pelayanan pembelajaran dan bertanggungjawab terhadap apa yang telah, sedang, dan akan dilakukannya kepada seluruh peserta didiknya.

Guru merupakan suatu profesi, yang berarti suatu jabatan yang memerlukan keahlian khusus sebagai guru dan tidak dapat dilakukan oleh sembarang orang di luar bidang pendidikan. Sehingga sebelum menjadi 
guru, pengelola atau manager sebuah lembaga pendidikan berkewajiban menjamin setiap guru yang akan mengajar mempunyai kemampuan yang sesuai atas dasar pendidikan, pelatihan, keterampilan, dan pengalaman yang dimiliki oleh guru tersebut. Selanjutnya, baik guru maupun pimpinan lembaga pendidikan secara bersama-sama dan penuh kesadaran melakukan berbagai upaya peningkatan kualitas diri dengan baik untuk mencapai tujuan pendidikan yang diharapkan. Kegiatan-kegiatan tersebut harus dapat dilakukan dalam sebuah wadah manajemen yang baik dan professional dengan nuansa pendidikan. Sehingga dengan begitu, lembaga-lembaga pendidikan diharapkan mampu mewujudkan peranannya secara efektif dengan berbagai keunggulan yang dimiliki.

Undang-Undang Republik Indonesia Nomor. 14 Tahun 2005 tentang guru pasal: 1 ayat: 1 guru adalah pendidik professional dengan tugas utama mendidik, mengajar, membimbing, mengarahkan, melatih, menilai dan mengevaluasi peserta didik pada pendidikan anak usia dini jalur pendidikan formal, pendidikan dasar, dan pendidikan menengah. Ayat: 3 Profesional adalah pekerjaan atau kegiatan yang dilakukan oleh seseorang dan menjadi sumber penghasilan kehidupan yang memerlukan keahlian, kemahiran, atau kecakapan, yang memenuhi standar mutu atau norma tertentu serta memerlukan pendidikan profesi. Pada Bab II pasal: 2 ayat: 1 guru mempunyai kedudukan sebagai tenaga professional pada jenjang pendidikan dasar, pendidikan menengah, pendidikan anak usia dini pada jalur pendidikan formal yang diangkat sesuai dengan peraturan perundang-undangan.

Kabupaten Halmahera Timur merupakan salah satu kabupaten pemekaran di Provinsi Maluku Uatara yang ditetapkan dengan Undang-Undang Nomor 1 Tahun 2003. Dengan lahirnya kabupaten tersebut maka Kabupaten Halmahera Timur memiliki 4 kecamatan dan 4 cabang dinas pendidikan di masing-masing kecamatan serta 73 Desa. Pada tahun 2016 jumlah Sekolah Dasar Negeri (SDN) di Kabupaten Halmahera Timur 73 buah bangunan yang terdiri dari 633 tenaga guru sekolah dasar negeri, 10.123 siswa. Sekolah Menengah Pertama Negeri (SMPN) memiliki 13 gedung sekolah yang terdiri dari 376 jumlah tenaga pengajar dan 3540 siswa, sementara Sekolah Menengah Atas Negeri (SMAN) terdapat 5 gedung sekolah terdiri dari 230 tenaga guru dan 2538 siswa. Demikian juga dengan sumber daya guru/tingkat pendidikan guru yaitu terdiri dari guru sekolah dasar negeri setara SLTA (SPG, SGO, KPG, PGA) 59,5 persen, D2 34,9 persen, (S1) 0,0 persen. Pada guru sekolah menengah pertama negeri strata D2 37,0 persen, strata satu (S1) 62,2 persen serta setara SLTA 0,8 persen. Guru pada sekolah menengah Atas negeri strata satu (S1) 97,3 persen dan setara SLTA 2,7 persen.

Berdasarkan observasi pada beberapa sekolah dan rekan guru di SD, SLTP, dan SMA di kabupaten Halmahera Timur, terdapat permasalahan-permasalahan yang terjadi. Kompetensi guru di SD, SLTP, dan SMA di Kabupaten Halmahera Timur masih relatif rendah. Kompetensi guru yang masih relatif rendah ini disebabkan oleh masih banyak guru SD, SLTP, dan SMA di Kabupaten Halmahera Timur yang belum memiliki motivasi kerja yang kuat untuk mengembangkan kompetensinya. Selain itu, peranan kepala sekolah yang bertanggungjawab atas manajemen pembinaan guru belum diterapkan secara optimal. Hal ini ditunjukan karena kurangnya perhatian kepala sekolah terhadap guru-guru yang mengalami kesulitan pada proses pembelajaran. Padahal proses pembinaan kepala sekolah memiliki fungsi penting dalam roda pendidikan sekolah, karena hampir setiap hari guru bertemu dengan kepala sekolah.

Upaya peningkatan pengetahuan dan kemampuan Dinas Pendidikan Kabupaten Halmahera Timur melalui pendidikan dan pelatihan belum terlaksana dengan baik. Fokus perhatian lebih pada pendidikan penjenjangan dari pada pendidikan untuk meningkatkan pengetahuan dan kemampuan teknis. Jumlah guru yang diberikan tugas belajar di perguruan tinggi masih dalam jumlah relatif kecil, juga termasuk mengikuti pendidikan penjenjangan, pendidikan teknis dan fungsional. Ukuran untuk menjadi peserta pendidikan dan pelatihan tidak semata-mata ditentukan oleh kemampuan dan potensi perkembangan seorang guru tetapi tergantung pada seberapa dekat hubungannya dengan penentu kebijakan. 
Kondisi keberadaan tenaga guru sebagaimana diuraikan dengan mempertimbangkan potensi sumber daya manusia tersedia memperlihatkan perlunya upaya nyata, berkesinambungan dan terpadu dari pemerintah daerah Kabupaten Halmahera Timur khususnya Dinas Pendidikan Kabupaten Halmahera Timur melalui Biro Kepegawaian Pemda Kabupaten Halmahera Timur sebagai operasional kebijakan di bidang kepegawaian untuk memanfaatkan peluang meningkatkan pengadaan dan pemerataan kebutuhan tenaga guru serta meningkatkan kompetensinya. Beberapa kendala yang ditemui di lapangan adalah; (1) Belum adanya pemerataan kebutuhan tenaga guru di lingkungan Dinas Pendidikan kabupaten Halmahera Timur; (2) Belum adanya kompetensi guru di Dinas Pendidikan kabupaten Halmahera Timur; (3) Pengembangan kompetensi guru di lingkungan Dinas Pendidikan kabupaten Halmahera Timur belum berjalan secara optimal; (4) Masih adanya kesenjangan kebutuhan guru yang terjadi di sekolah dilingkungan Dinas Pendidikan kabupaten Halmahera Timur. Berpijak dari uraian yang dikemuakan diatas maka pertanyaan yang diajukan dalam tulisan ini adalah bagaimana perencanaan, rekrutmen, pengembangan dan kebutuhan tenaga guru dilingkunganDinas Pendidikan Kabupaten Halmahera Timur?

\section{METODE PENELITIAN}

Penelitian ini merupakan desain penelitian deskriptif dengan menggunakan metode kualitatif.Penelitian kualitatif lebih banyak ditujukan pada pembentukan teori substantif berdasarkan dari konsep-konsep yang timbul dari data empiris. Untuk mendapatkan gambaran tentang manajemen kompetensi guru di Dinas Pendidikan Halmahera Timur. Penelitian ini menggunakan studi kasus dengan mengevaluasi keadaan yang terjadi pada saat penelitian dengan yang seharusnya dilaksanakan yaitu mengamati dan mengevaluasi kompetensi guru/tingkat pendidikan guru, pengembangan profesionalisme/diklat guru, di sekolah.

Penelitian ini dilaksanakan diDinas Pendidikan Kabupaten Halmahera Timur Provinsi Maluku Utara yang membawahi empat Unit Pelaksana Teknis Daerah (UPTD) dimasing-masing kecamatan, Sekolah Dasar Negeri (SDN), Sekolah Menengah Pertama Negeri (SMPN), dan Sekolah Menengah Atas Negeri (SMAN). Peneliti memilih lokasi ini karena dilihat dari jumlah guru yang ada bahwa sebagian besar guru yang belum memilki kualifikasi akademik, sehingga kualitas guru masih dikatakan masih sangat rendah. Di samping itu peneliti tidak memiliki keterkaitan dengan Dinas Pendidikan Kabupaten Halmahera Timur yang memungkinkan peneliti terlibat secara langsung. Dengan kondisi seperti ini, kecurigaan terhadap subjektifitas hasil penelitian dapat dihindari.

Teknik atau tata cara pengumpulan data dalam penelitian ini adalah; (1) Dokumentasi. Dokumentasi merupakan suatu teknik pengumpulan data melalui bahan-bahan tertulis yang berkaitan dengan masalah penelitian. Menurut Sugiyono (2010: 326), bahwa dokumen merupakan catatan peristiwa yang sudah berlalu. Pengumpulan data dengan dokumen bisa berbentuk tulisan, gambar, atau karya-karya monumental, dari seseorang. Dokumen yang berbentuk tulisan misalnya, catatan harian, sejarah kehidupan, ceritra, biografi, peraturan, kebijakan. Dokumen yang berbentuk gambar misalnya foto, gambar hidup, sketsa dan lain-lain; (2) Observasi. Berkenaan dengan penelitian ini, peneliti menggunakan teknik observasi (pengamatan) partisipatif, dimana peneliti sambil melakukan pengamatan, sekaligus ikut terlibat melakukan apa yang dikerjakan oleh sumber data. Obyek yang diamati menurut Spradley (dalam Sugiyono, 2010; 313) adalah situasi sosial yang terdiri dari tiga komponen yaitu place (tempat), acktor (pelaku), dan aktivities (aktivitas); (3) Wawancara. Jenis wawancara yang dilakukan adalah wawancara semi struktur dengan alasan agar peneliti dapat lebih bebas dan leluasa dalam mengajukan pertanyaan-pertanyaan tanpa terikat oleh suatu susunan pertanyaan yang telah disiapkan sebelumnya. Menurut Sugiyono, 2010: 318), wawancara semistruktur sudah termasuk dalam kategori in-depth interview, dimana dalam pelaksanaannya lebih bebas bila dibandingkan dengan wawancara terstruktur. Disamping itu bahwa, dengan wawancara terstruktur, pihak yang diajak wawancara lebih terbuka mengemukakan pendapat dan ide-idenya. 
Subhan Hayun \& Rustam Hasyim. 2018. teachers' distribution, the developing teacher's competence

Data yang diperoleh melalui sejumlah instrument dievaluasi dengan menggunakan teknik analisis kualitatif. Melalui teknik ini, hasil penelitian dideskripsikan dengan menggambarkan secara lengkap terhadap kondisi subjek penelitian. Analisis data merupakan proses penyususun data agar dapat terpola secara sistematis kemudian diinterpretasikan untuk menjelaskan makna itu sendiri. Mengingat penelitian ini merupakan penelitian kualitatif, maka proses analisis data dilakukan secara terus menerus mulai dari tahap pengumpulan data. Untuk mengecek keabsahan data maka dilakukan beberapa hal, Miles dan Huberman (1994. 16), mencakup empat alur kegiatan yang terjadi secara bersamaan, yaitu: Pengumpulan data, reduksi data, penyajian data, dan penarikan kesimpulan/verifikasi.

\section{PEMBAHASAN}

Dinas Pendidikan Kabupaten Halmahera Timur merupakan unsur pelaksana pemerintah daerah di bidang pendidikan, yang dipimpin oleh seorang kepala yang berada dibawah dan bertangungjawab kepada bupati melalui sekertaris daerah, serta mampunyai tugas melaksanakan kewenangan otonomi daerah di bidang pendidikan dalam rangka tugas desentralisasi. Dalam menjalangkan fungsi tersebut maka ditetapkan susunan organisasi perangkat Dinas Pendidikan Kabupaten Halmahera Timur yang terdiri dari; Kepala Dinas, Kabag Tata Usaha, Kasubag Umum \& Kepegawaian, Kasubag Perencanaan \& Keuangan, Kasubdin Dikdasmen, Kasubdin Bidang Sarana \& Prasarana, Kasubdin Tenaga Kependidikan, serta Kelompok jabatan Fungsional. Untuk menjalangkan organisasi pendidikan, maka dirumuskan visi dan misi sebagai arah kebijakan dan landasan untuk tercapainya tujuan diharapkan. Adapun Visi Dinas: "Pembangunan Dari, Oleh, dan Untuk Rakyat Dalam Kerangka Mewujudkan Halmahera Timur Yang Bersatu, Maju, Sejahtera, Aman dan Damai". Oleh karena itu, berdasarkan hasil penelitian maka berikut ini akan dijelaskan hasil penelitian tentang manajemen sumberdaya manusia tenaga pendidik oleh Dinas Pendidikan Kabupaten Halmahera Timur sebagai berikut:

\section{A. Perencanaan Sumber Daya Manusia Tenaga Pendidik}

Dari hasil observasi dan wawancara sejumlah narasumber diperoleh informasi bahwa dalam proses perencanaan sumberdaya manusia tenaga pendidik, Dinas Pendidikan Kabupaten Halmahera Timur melaksanakan beberapa tahapan penting yang dilakukan teratur dan terencana meliputi; pertama, sebelum melaksanakan proses perencanaan sumber daya manusia tenaga pendidik dinas pendidikan Kabupaten Halmahera Timur terlebih dahulu mengadakan evaluasi dan analisis. Evaluasi dan analisis yang dilakukan setiap tahun, ini bertujuan untuk mengetahui sekolah yang kekurangan dan memerlukan tenaga pendidik.

Kedua, setelah hasil evaluasi dan analisis diketahui, Dinas Pendidikan Kabupaten Halmahera Timur mengadakan rapat kerja sama dalam rangka mengusulkan perencanaan tenaga pendidik dengan instansi Badan Kepegawaian Daerah (BKD). Tujuan koordinasi ini agar perencanaannya berjalan dengan lancar, jelas terarah dan sesuai dengan kebutuhan tenaga pendidik dinas pendidikan Dinas Pendidikan Kabupaten Halmahera Timur. Hal ini dimaksudkan agar perencanaan tenaga pendidik harus membutukan penerapan yang rasional, dianalisis, dan sistematis prosesnya dapat berjalan efektif dan efisien serta sesuai dengan kebutuhan dan tujuan pendidikan.

Ketiga, setelah dilakukan rapat dengan pihak-pihak terkait dengan Badan Kepegawaian daerah (BKD) dan Sekertariat Daerah, selanjutnya Dinas Pendidikan Kabupaten Halmahera Timur melakukan proses perencanaan. Dalam proses perencanaan tenaga pendidik, Dinas Pendidikan Kabupaten Halmahera Timur selalu berpedoman pada kebutuhan dan kekurangan guru pada semua jenjang pendidikan (TK-SMA), dan Keempat, setelah perencanaan sumberdaya tenaga pendidik berhasil disusun, maka pelaksanaanya diserahkan kepada kepala bagian tata usaha yang membawahi kepala sub bagian umum kepegawaian. 
Tabel 1. Data Jumlah Siswa dan Guru SD Negeri Kabupaten Halmahera Timur tahun 2011/2012

\begin{tabular}{|c|c|c|c|c|c|c|c|}
\hline \multirow[t]{2}{*}{ No } & \multirow{2}{*}{$\begin{array}{c}\text { Wilayah } \\
\text { Per Kecamatan }\end{array}$} & \multicolumn{2}{|c|}{ Jumlah Siswa } & \multirow[b]{2}{*}{ Jumlah } & \multicolumn{2}{|c|}{ Jumlah Guru } & \multirow[b]{2}{*}{ Jumlah } \\
\hline & & Laki-laki & Perempuan & & Laki-laki & Perempuan & \\
\hline 1 & Kecamatan Maba selatan & 4277 & 4039 & 8316 & 104 & 271 & 375 \\
\hline 2 & Kecamatan Maba Utara & 3596 & 3695 & 7291 & 75 & 258 & 333 \\
\hline 3 & Kecamatan Wasilei Selatan & 1261 & 1410 & 2671 & 103 & 75 & 178 \\
\hline 4 & Kecamatan Wasilei Utara & 293 & 276 & 569 & 29 & 18 & 47 \\
\hline \multicolumn{2}{|c|}{ Jumlah } & 9427 & 9420 & 18847 & 311 & 622 & 933 \\
\hline
\end{tabular}

Sumber: Dinas Pendidikan Kabupaten Halmahera Timur 2015

Hasil penelitian menemukan bahwa distribusi tenaga guru di masing-masing sekolah belum merata di setiap jenjang pendidikan (SD, SMP, dan SMA). Sehingga menyebabkan ada sekolah yang memiliki kelebihan guru dan sekolah yang mengalami kekurangan guru. Sekolah yang memiliki kelebihan guru hampir tersebar di Kecamatan Maba Utara dan Kecamatan Wasilei Selatan. Sementara sekolah yang mengalami kekurangan guru tersebar di beberapa Kecamatan Wasilei Utara dan Kecamatan Maba Selatan.

Dalam mengatasi kebutuhan akan tenaga guru tersebut, Dinas Pendidikan Kabupaten Halmahera Timur telah melakukan perencanaan tenaga guru dengan melakukan koordinasi dengan Kabid Ketenagaan Dinas Pendidikan Nasional Kabupaten Halmahera Timur, sehingga diharapkan tidak akan terjadi kekurangan guru pada semua jenjang pendidikan di Kabupaten Halmahera Timur. Terkait dengan perencanaan, Dinas Pendidikan telah membuat perencanaan, melaksanakan dan mengevaluasi kebutuhan tenaga guru di sekolah melalui tiga tahapan; yakni, pertama, perencanaan jangka pendek yakni perencanaan tahunan atau perencanaan yang dibuat untuk dilaksanakan dalam waktu kurang dari 5 tahun, sering disebut sebagai rencana operasional. Perencanaan ini merupakan penjabaran dari rencana jangka menengah dan jangka panjang. Kedua, perencanaan jangka menengah mencakup kurun waktu diatas 5-10 tahun. Perencanaan ini merupakan penjabaran dari rencana jangka panjang, tetapi sudah lebih bersifat operasional, dan ketiga, perencanaan jangka panjang meliputi cakupan waktu diatas 10 tahun sampai dengan 25 tahun.

Dengan demikian dapat disimpulkan bahwa perencanaan tenaga pendidik oleh Dinas Pendidikan Kabupaten Halmahera Timur merupakan suatu upaya atau langkah-langkah yang dibuat untuk merencanakan sumberdaya manusia tenaga pendidik dimasa yang akan datang dalam rangka memenuhi kebutuhan guru di setiap sekolah. Perencanaan yang baik hendaknya menghasilkan tenaga kependidikan yang baik, dan relevan dengan kebutuhan pembangunan. Dalam hal ini Dinas Pendidikan Kabupaten Halmahera Timur dalam perencanaan tenaga pendidik berpedoman pada kebutuhan guru pada setiap sekolah dan sesuai dengan bidang studi masing-masing yang diusulkan oleh para kepala sekolah. Perencanaan akan terlaksana dengan sebaik-baiknya apabila para pemimpin pendidikan sungguh-sungguh yakin pentingnya pendidikan dapat memberikan dukungan dalam perumusan rencana pengembangan sumberdaya manusia.

\section{B. Rekrutmen Sumber Daya Manusia Tenaga Pendidik}

Rekrutmen tenaga pendidik (guru) pada Kantor Dinas Pendidikan Kabupaten Halmahera Timur dilakukan mengacu pada kebutuhan dan kekurangan guru pada setiap sekolah yang telah direncanakan sebelumnya dengan menggunakan seleksi akademik, administrasi, kesehatan, dan kualifikasi yang telah ditentukan oleh Badan Kepegawaian Daerah (BKD). Proses perekrutan tenaga pendidik pada Dinas Pendidikan Kabupaten Halmahera Timur menetapkan tiga jenis tes untuk menyeleksi yaitu; (1) Seleksi administrasi, seleksi kesehatan, seleksi akademisi dan materi seleksi tersebut sudah ditentukan oleh pemerintah pusat; (2) Penempatan bagi guru lama dilakukan dengan promosi, rotasi, dan demosi; (3) Menyelenggarakan pendidikan dan pelatihan sesuai dengan kebutuhan untuk meningkatkan kinerja guru. 
Berdasarkan hasil penelitian bahwa rekruitmen tenaga pendidik oleh Dinas Pendidikan Kabupaten Halmahera Timur, bertujuan untuk mendapatkan guru yang profesional dan mempunyai kualifikasi yang terbaik. Rekruitmen guru baru perlu diadakan untuk memenuhi kebutuhan sekolah-sekolah yang masih banyak membutuhkan guru kelas khususnya guru Sekolah Dasar dan guru mata pelajaran untuk SMP dan SMA yang tersebar di beberapa Kecamatan di Kabupaten Halmahera Timur seperti Kecamatan Maba Utara dan Kecamatan Wasilei Selatan. Perekrutan guru baru sangat dibutuhkan untuk mengisi posisi jabatan yang sesuai bidangnya dan dilakukan sesuai dengan kebutuhan sekolah, dengan persyaratan yang telah ditentukan.

Dengan demikian rekrutmen yang dilakukan tidak hanya sekedar mengisi kekosongan guru atau sekedar mendapatkan guru yang biasa saja, tetapi guru yang dapat berdedikasi dan profesional di bidangnya sehingga dapat meningkatkan mutu pendidikan sekolah tersebut. Guru ideal yang diperlukan adalah guru yang memahami benar akan profesinya. Hal ini karena kualitas guru yang digunakan oleh Dinas Pendidikan Kabupaten Halmahera Timur sangat bergantung pada prosedur rekruitmen dan seleksi yang dilaksanakan. Untuk dapat mengetahui tingkat pendidikan dan rasio Guru-Murid pada SMP dan SMA Kabupaten Halmahera Timur dapat dilihat pada Tabel berikut.

Tabel 2. Data jumlah siswa dan guru SMP Negeri Kabupaten Halmahera Timur Tahun 2011/2012

\begin{tabular}{lccccccc}
\hline \multirow{2}{*}{ No } & Wilayah Per Kecamatan & \multicolumn{2}{c}{ Jumlah Siswa } & & \multicolumn{2}{c}{ Jumlah Guru } & \\
\cline { 3 - 3 } & Laki-laki & Perempuan & \multirow{2}{*}{ Jumlah } & \multirow{2}{*}{ Laki-laki } & Perempuan & Jumlah \\
A. Kecamatan Maba Selatan & & & & & & \\
1 & SMP Negeri 1 Maba & 678 & 784 & 1462 & 25 & 45 & 70 \\
2 & SMP Negeri 2 Maba & 627 & 612 & 1239 & 24 & 46 & 70 \\
3 & SMP Negeri 5 Maba & 141 & 169 & 310 & 15 & 20 & 35 \\
& Jumlah & 1446 & 1565 & $\mathbf{3 0 1 1}$ & 64 & 111 & $\mathbf{1 7 5}$
\end{tabular}

\section{B. Kecamatan Maba Utara}

1 SMPN 3 Maba 159

2 SMPN 4 Maba $\quad 564$

3 SMPN 6 Maba 484

4 SMPN 7 Maba

Jumlah

\section{Kecamatan Wasile Selatan}

1 SMPN 8 Wasilei

2 SMPN 10 Wasile

3 SMPN 11 Wasilei

4 SMPN 13 Wasilei

Jumlah

\section{2}

1439

56

50

25

52

183
156

581

236

319

1295

\section{2}

57

45

65

219

\section{5}

1145

720

551

2731

108

107

70

117

402

\section{1}

34

30

22

97

135

\section{4}

40

43

28

135

$\begin{array}{cc}7 & 12 \\ 3 & 5 \\ 5 & 8 \\ 6 & 9 \\ 21 & \mathbf{3 4}\end{array}$

\section{Kecamatan Wasile Utara}

\begin{tabular}{llcccccc}
$\mathbf{1}$ & SMPN 9 Wasile & 94 & 92 & 186 & 7 & 8 & 15 \\
$\mathbf{2}$ & SMPN 12 Wasile & 97 & 113 & 210 & 4 & 16 & 20 \\
& Jumlah & 191 & 205 & $\mathbf{3 9 6}$ & 11 & 24 & $\mathbf{3 5}$ \\
\hline
\end{tabular}

Sumber: Dinas Pendidikan Pemuda dan Olahraga Kabupaten Halmahera Timur 2015 
Keberhasilan Dinas Pendidikan Kabupaten Halmahera Timur untuk mendapatkan guru yang berkualitas tidak lepas dari upaya untuk mengadakan rekruitmen yang baik. Rekruitmen guru yang baik akan memberikan hasil yang positif bagi sekolah. Semakin efektif proses rekruitmen dan seleksi penerimaan guru, semakin besar kemungkinan untuk mendapatkan guru yang tepat. Selain itu, rekruitmen dan seleksi yang efektif akan berpengaruh langsung pada produktivitas dan kinerja guru. Dengan demikian, rekruitmen yang dilaksanakan oleh Dinas Pendidikan Kabupaten Halmahera Timur untuk mencari sumberdaya manusia guna menutupi kekurangan guru kelas atau mata pelajaran di setiap jenjang pendidikan di Kabupaten Halmahera Timur dapat diatasi. Selain guru, prinsip yang dipakai Dinas Pendidikan Kabupaten Halmahera Timur ketika mengadakan rekruitmen Kepala Sekolah dan Pengawas Sekolah adalah benar-benar terdapat jabatan yang kosong sehingga membutuhkan tenaga sumberdaya manusia yang profesional. Dalam merekrut Kepala Sekolah dan Pengawas Sekolah selalu memperhatikan analisis jabatan sehingga dapat merekrut orang yang tepat dan sesuai dengan jabatan tersebut. Di samping itu, dalam rekruitmen tenaga pendidik juga dapat terhindar dari unsur KKN sehingga tidak ada pihak yang dirugikan.

Dengan demikian dapat disimpulkan bahwa rekruitmen tenaga pendidik yang dilaksanakan oleh Dinas Pendidikan Kabupaten Halmahera Timur merupakan serangkaian aktivitas untuk mendapatkan guru yang tepat guna mengisi lowongan atau kekurangan guru yang memiliki kompetensi dan sesuai dengan kualifikasi yang telah ditentukan oleh Dinas Pendidikan. Pelaksanaan rekuitmen guru didasari untuk memenuhi kebutuhan guru dan sesuai dengan kualifikasi yang dibutuhkan oleh sekolah. Dengan demikian, Kantor Dinas Pendidikan Kabupaten Halmahera Timur dalam mengadakan rekruitmen para tenaga pendidik untuk mengisi kekurangan guru yang dibutuhkan sekolah disesuikan dengan aturan Badan Kepegawaian Daerah.

\section{Pengembangan Sumber Daya Manusia Tenaga Pendidik}

Program pembinaan sumberdaya manusia (pendidik) oleh Dinas Pendidikan Kabupaten Halmahera Timur meliputi; program diklat para guru pada setiap jenjang pendidikan (SD, SMP dan SMA). Peningkatan proses pendidikan dilakukan melalui pembinaan kepribadian, sikap, dan kemampuan teknis profesionalisme guru dilakukan melalui penataran dan pemanfaatan wadah Kelompok Kerja Guru (KKG), Kelompok Guru Mata Pelajaran (MGMP), Kelompok Kerja Kepala Sekolah (KKKS), Dan Kelompok Kerja Pengawas Sekolah (KKPS). Pembinaan mutu guru juga dilakukan program penyetaraan Guru Sekolah Dasar (PGSD). Bertujuan meningkatkan mutu lulusan sekolah dasar melalui peningkatan pendidikan guru minimal pada jenjang Diploma Dua (D-II). Pembinaan mutu guru juga dilakukan melalui promosi jabatan guru. Promosi jabatan meliputi jabatan inti, guru pemandu bidang studi, kepala sekolah, maupun pengawas sekolah. Promosi juga memperhatikan sikap dan kepribadian dalam melaksanakan tugas yang meliputi kegiatan guru di masyarakat, organisasi sosial dan keagamaan, kepramukaan, maupun kepengurusan dalam organisasi profesi guru. Program pembinaan guru dilakukan melalui penataran-penataran yang berkaitan dengan seluruh bidang studi yang diajarkan di sekolah.

Dari hasil observasi dan wawancara sejumlah narasumber diperoleh informasi bahwa pembinaan mutu guru SD, SMP dan SMA di Kabupaten Halmahera Timur bertujuan untuk meningkatkan mutu hasil pendidikan melalui peningkatan sikap, kepribadian, dan kemampuan teknis profesional guru. Program pembinaan Dinas Kabupaten Halmahera Timur dilakukan melalui Pusat Pengembangan Penataran Guru (PPPG) untuk setiap bidang studi. Program pembinaan meliputi; peningkatan mutu kemampuan teknis, kepribadian dan sikap profesional guru dalam rangka meningkatkan mutu guru melalui proses pengajaran. Pembinaan mutu guru juga dilakukan di tingkat kecamatan yang dilaksanakan oleh UPTD bersama dengan Dinas Pendidikan. Operasionalisasi program tersebut dilaksanakan oleh sekolah melalui Gugus Sekolah, dan selanjutnya diterapkan di tingkat sekolah oleh kepala sekolah bersama guru. Disamping itu, kenaikan pangkat dengan sistem angkat kredit membuat para guru bergairah mengikuti program-program pembinaan. Bagi badan 
Administrasi Kepegawaian Negara kenaikan pangkat pada hakekatnya merupakan penghargaan atas prestasi guru bersangkutan apabila diberikan kepada orang dan waktu yang tepat.

Namun demikian, masih terdapat sebagian guru belum mendapat kegiatan pendidikan peningkatan kompetensi (diklat, pelatihan dan penataran) secara maksimal dan belum merata di setiap jenjang pendidikan. Sebagian besar guru sekolah dasar adalah lulusan D-II. Disamping berkualifikasi lulusan jenjang D-II, guru-guru dituntut memiliki kompetensi pedagogik, kompetensi kepribadian, kompetensi sosial, dan kompetensi profesional yang diperoleh melalui pendidikan profesi atau sertifikasi guru. Upaya peningkatan kompetensi guru melalui program kegiatan pendidikan dan latihan di semua jenjang pendidikan, apakah itu guru kelas maupun guru mata pelajaran namun realisasinya belum secara menyeluruh karena disesuaikan dengan alokasi dana. Distribusi tenaga guru di masing-masing sekolah dari TK hingga SMA belum merata, ada sekolah yang memiliki kelebihan dan sekolah yang mengalami kekurangan guru. Di samping itu, masih banyak juga guru yang belum disertifikasi sebagai tenaga pendidik profesional.

Tabel 3. Data Jumlah Siswa dan Guru SMA Negeri Kabupaten Halmahera Timur Tahun 2011/2012

\begin{tabular}{|c|c|c|c|c|c|c|c|}
\hline \multirow[t]{2}{*}{ No } & \multirow{2}{*}{$\begin{array}{l}\text { Wilayah Per } \\
\text { Kecamatan }\end{array}$} & \multicolumn{2}{|c|}{ Jumlah Siswa } & \multirow[b]{2}{*}{ Jumlah } & \multicolumn{2}{|c|}{ Jumlah Guru } & \multirow[b]{2}{*}{ Jumlah } \\
\hline & & Laki-laki & Perempuan & & Laki-laki & Perempuan & \\
\hline \multicolumn{8}{|c|}{ A. Kecamatan Maba Selatan } \\
\hline 1 & SMA Negeri 1 Haltim & 450 & 570 & 1020 & 27 & 24 & 51 \\
\hline \multirow[t]{2}{*}{2} & SMA Negeri 4 Haltim & 453 & 633 & 1086 & 23 & 30 & 53 \\
\hline & Jumlah & 903 & 1203 & 2106 & 50 & 54 & 104 \\
\hline \multicolumn{8}{|c|}{ B. Kecamatan Maba Utara } \\
\hline 1 & SMA Negeri 2 Haltim & 798 & 847 & 1645 & 50 & 35 & 85 \\
\hline 2 & SMA Negeri 3 Haltim & 691 & 737 & 1428 & 32 & 43 & 76 \\
\hline 3 & SMA Negeri 7 Haltim & 239 & 192 & 431 & 15 & 18 & 33 \\
\hline 4 & SMA Negeri 6 Haltim & 15 & 19 & 34 & 3 & 5 & 8 \\
\hline & Jumlah & 1743 & 1795 & 3538 & 100 & 101 & 202 \\
\hline \multicolumn{8}{|c|}{ C. Kecamatan Wasile Selatan } \\
\hline & SMA Negeri 8 Haltim & 69 & 74 & 143 & 6 & 13 & 19 \\
\hline \multicolumn{8}{|c|}{ D. Kecamatan Wasile Utara } \\
\hline 1 & SMA Negeri 5 Haltim & 73 & 76 & 149 & 3 & 5 & 8 \\
\hline
\end{tabular}

Sumber: Dinas Pendidikan Pemuda dan Olahraga Kabupaten Halmahera Timur 2015

Program pembinaan dan pengembangan tenaga pendidik oleh Dinas Pendidikan dilakukan berdasarkan kebutuhan institusi, kelompok, maupun individu tenaga pendidik sendiri. Pengembangan tenaga pendidik oleh Dinas Pendidikan Kabupaten Halmahera Timur dimaksudkan untuk merangsang, memelihara, dan meningkatkan kualitas guru dalam memecahkan masalah-masalah di sekolah dalam kerangka pembinaan profesi dan karier. Pengembangan karier guru menunjukkan adanya peningkatan status seorang guru dalam menjalankan tugasnya. Kantor Dinas Pendidikan Kabupaten Halmahera Timur dalam melakukan pengembangan karier guru, menyesuaikan dengan kebutuhan pekerjaan sekolah dengan memenuhi kualifikasi status guru, tunjangan guru, dan sertifikasi guru yang harus dipenuhi. Pengembangan tenaga pendidik dilakukan melalui kegiatan pendidikan dan pelatihan. Kegiatan ini bertujuan untuk; (1) Menghilangkan kesenjangan kinerja tenaga pendidik yang disebabkan mereka bertugas tidak sesuai dengan yang diharapkan; (2) Meningkatkan kemampuan angkatan kerja yang lentur dan mampu menyesuaikan diri 
dengan perkembangan teknologi baru yang dihadapi sekolah; dan (3) Meningkatkan keterikatan (komitmen) tenaga pendidik terhadap sekolah dan membina persepsi bahwa sekolah itu tempat yang baik untuk bertugas.

Sebagai tenaga profesional, guru dituntut meningkatkan profesionalisme dengan melalui belajar sendiri maupun melalui program pembinaan dan pengembangan yang telah ditetapkan oleh Dinas Pendidikan. Berdasarkan hasil penelitian bahwa peningkatan profesionalisme guru di Dinas Pendidikan Kabupaten Halmahera timur dilakukan melalui kegiatan seminar, pelatihan, dan pendidikan.Pembinaan profesi guru meliputi pembinaan kompetensi pedagogik, kompetensi kepribadian, kompetensi profesional, dan kompetensi sosial. Upaya yang dapat dilakukan guru untuk meningkatkan kompetensinya adalah berpartisipasi dalam forum atau kegiatan ilmiah seperti; membuat karya tulis ilmiah, karya seni, dan karya teknologi, melaksanakan penelitian/pengkajian kerja profesionalnya baik secara individual maupun kelompok.

Dengan demikian dapat disimpulkan bahwa pengembangan sumberdaya manusia tenaga pendidik yang dilakukan oleh Kantor Dinas Pendidikan Kabupaten Halmahera Timur dimulai dari perencanaan hingga implementasinya. Dalam pendidikan, pengembangan SDM tenaga pendidik adalah tugas Dinas Pendidikan dalam membantu para guru untuk meningkatkan kompetensinya menjadi guru yang profesional. Dalam pengembangan sumberdaya manusia tenaga pendidik Dinas Pendidikan Kabupaten Halmahera Timur dilakukan dengan cara pelatihan-pelatihan, kursus, diklat, pendidikan lanjut, penambahan gelar dan promosi jabatan.

\section{Evaluasi Sumber Daya Manusia Dinas Pendidikan}

Pelaksanaan evaluasi kinerja guru oleh Dinas Pendidikan Kabupaten Halmahera Timur dilakukan dengan menggunakan standar pelayanan minimal yang memenuhi unsur dalam penilain pelaksanaan pekerjaan sebagai pedoman dan tolak ukur untuk mengevaluasi kinerja pegawai, melalui evaluasi kinerja setiap hari, evaluasi kinerja setiap bulan, dan evaluasi kinerja akhir tahun. Evaluasi kinerja guru oleh Dinas Pendidikan Kabupaten Halmahera Timur dilakukan dengan tujuan: (1) Evaluasi terhadap sesuatu yang sudah dikerjakan oleh guru, biasanya berkaitan dengan masalah seperti; kompensasi, penambahan/pengurangan guru, sistem seleksi pekerja; (2) Pengembangan guru yang berkaitan dengan; (a) Pemberian umpan balik terhadap kinerja yang telah dihasilkan; (b) Pemberian arah perbaikan kinerja dimasa akan dating; (c) Proses indentifikasi adanya kebutuhan terhadap pelatihan dan pengembangan.

Dalam mengevaluasi masalah kesenjangan tenaga guru di Kabupaten Halmahera Timur, hasil penelitian menemukan bahwa, terdapat kekurangan guru kelas dan guru mata pelajaran pada semua jenjang pendidikan. Hal ini disebabkan karena pendistribusian yang tidak merata dalam penempatan guru kelas maupun guru mata pelajaran oleh Dinas Pendidikan Kabupaten Halmahera Timur. Masalah kesenjangan tenaga guru dapat dilihat pada rasio perbandingan jumlah guru, siswa, maupun rombongan belajar tidak proporsional. Ketidakseimbangan jumlah tersebut dibuktikan dengan terdapat kelebihan guru kelas dan mata pelajaran pada semua jenjang pendidikan pada Sekolah yang tersebar di Kecamatan Maba Utara dan Kecamatan Wasilei Selatan.Sementara sekolah yang mengalami kekurangan guru tersebar di beberapa Kecamatan Wasilei Utara dan Kecamatan Maba Selatan. 
Subhan Hayun \& Rustam Hasyim. 2018. teachers' distribution, the developing teacher's competence

Tabel 4. Keadaan Tenaga Guru dan Tingkat Pendidikan Guru Mengajar

\begin{tabular}{|c|c|c|c|c|c|c|c|c|c|c|c|c|c|c|}
\hline \multirow{2}{*}{ No } & \multirow{2}{*}{$\begin{array}{l}\text { Jenjang } \\
\text { Pendidika } \\
\text { n }\end{array}$} & \multirow{2}{*}{$\begin{array}{l}\text { Jlh } \\
\text { Sklh }\end{array}$} & \multicolumn{5}{|c|}{ Jumlah } & \multirow{2}{*}{$\begin{array}{l}\text { Rom } \\
\text { Bel. }\end{array}$} & \multicolumn{5}{|c|}{ Strata Pendidikan } & \multirow[t]{2}{*}{ Rasio } \\
\hline & & & $\begin{array}{r}\text { Guru } \\
\text { Kls }\end{array}$ & $\begin{array}{l}\text { Guru Pend. } \\
\text { Agama }\end{array}$ & $\begin{array}{c}\text { Guru } \\
\text { Penjaskes }\end{array}$ & $\begin{array}{c}\mathrm{Jlh} \\
\text { guru }\end{array}$ & Siswa & & SLTA & $\mathrm{D} 2$ & D3 & S1 & $\mathrm{S} 2$ & \\
\hline 1 & SD & 83 & 688 & 116 & 129 & 933 & 18.847 & 576 & 40,5 & 59,5 & - & - & - & 20 \\
\hline 2 & SLTP & 13 & - & - & - & 476 & 6540 & 137 & 37,0 & - & 0,8 & 62,2 & - & 14 \\
\hline 3 & SLTA & 8 & - & - & - & 333 & 5936 & 133 & 2,7 & - & - & 97,3 & - & 18 \\
\hline
\end{tabular}

Sumber: Dinas Pendidikan Pemuda dan Olahraga Kabupaten Halmahera Timur 2015

Dengan demikian evaluasi kinerja tenaga pendidik Dinas Pendidikan Kabupaten Halmahera Timuradalah untuk menilai atau melihat keberhasilan dan kegagalan dalam melaksanakan kegiatan dan fungsi yang diamanahkan kepadanya sebagaimana visi dan misi Dinas Pendidikan yakni Terwujudnya Pendidikan Berkualitas. Evaluasi kinerja guru sebenarnya merupakan kegiatan lanjutan dari pengukuran kinerja, sehingga dalam melakukan evaluasi kinerja guru harus berpedoman pada ukuran-ukuran dan indikator yang telah disepakati dan ditetapkan.

Dengan demikian dapat disimpulkan bahwa evaluasi kinerja guru oleh Dinas Pendidikan Kabupaten Halmahera Timur pada dasarnya dilakukan untuk mengukur kinerja tenaga pendidik sekaligus untuk mengetahui seberapa baik performa seseorang guru dalam melaksanakan tugas pekerjaannya dan seberapa besar potensinya untuk berkembang. Untuk mengetahui apakah sumberdaya manusia (guru) yang dimiliki telah melaksanakan pekerjaan/jabatan sesuai dengan tugas dan tangungjawabnya, maka perlu dilakukan penilaian kerja untuk mengukur produktivitas kerjanya.Kinerja ini mencakup prestasi kerja, cara berkerja, kreativitas dan kemampuan mengembangkan karir. Dengan melakukan penilaian kerja juga dapat diketahui ketepatan atau ketidaktepatan seorang guru dalam melaksanakan pekerjaan, sehingga dapat menjadi bahan informasi berharga bagi Dinas Pendidikan dalam mengambil keputusan selanjutnya.

\section{KESIMPULAN}

Berdasarkan hasil penelitian dan pembahasan mengenai Manajemen kompetensi guru SD, SMP, dan SMA di Dinas Pendidikan Kabupaten Halmahera Timur, maka dapat ditarik beberapa kesimpulan yang berkaitan dengan penelitian ini. Adapun beberapa kesimpulan yang dapat dikemukakan dari penelitian ini sebagai berikut:

1. Kebutuahan tenaga guru sekolah dasar negeri pada UPTD kecamatan Maba Selatan, guru kelasnya cukup, guru mata pelajaran penjaskes maupun guru mata pelajaran pendidikan agama mengalami kelebihan. Guru sekolah dasar negeri pada UPTD kecamatan Maba Utara guru kelasnya cukup, guru mata pelajaran penjaskes mengalami kelebihan, sementara guru mata pelajaran pendidikan agama masih kurang. Guru sekolah dasar negeri pada UPTD kecamatan Wasilei Utara jumlah tenaga guru kelasnya masih kurang, guru mata pelajaran penjaskesmengalami kelebihan, sementaraguru mata pelajaran pendidikan agama sudah cukup. Kemudian Guru sekolah dasar negeri pada UPTD kecamatan Wasilei Selatan guru kelasnya masih sangat kurang, sementara guru mata pelajaran penjaskes dan guru mata pelajaran pendidikan agama sudah mengalami kelebihan. Kebutuhan tenaga guru Sekolah Menengah Pertama Negeri (SMPN), dilihat dari rasio antara guru dengan siswa sesuai dengan standar, kemudian perbandingan jumlah siswa dengan jumlah rombongan belajar terjadi pembengkakan (kelebihan siswa per kelas), perbandingan guru dengan rombongan belajar sudah sesuai standar. Kebutuhan tenaga guru Sekolah Menengah Atas Negeri (SMAN), perbandingan jumlah guru dengan jumlah rombongan belajar tidak berimbang terjadi 
pembengkakan di sejumlah kelas, kemudian perbandingan guru dengan siswa sudah sesuai standar.

2. Kompetensi guru sekolah dasar negeri masing-masing sekolah di UPTD masih minim. Kompetensi guru Sekolah Menengah Pertama Negeri perlu ditingkatkan untuk memenuhi standar profesionalisme. Sekolah Menengah Atas Negeri (SMAN) guru sudah kebanyakan memiliki kualifikasi pendidikan Strata Satu (S1).

Pendidikan, pelatihan, dan pengembangan merupakan proses yang ditempuh oleh guru pada saat menjalani tugas-tugas kedinasan. Kegiatan ini diorganisasikan secara beragam dan berspektrum luas dengan tujuan untuk meningkatkan kompetensi, keterampilan, sikap, pemahamann dan performansi yang dibutuhkan oleh guru saat ini dan di masa mendatang. Kegiatan ini merujuk pada kegiatan belajar yang didesain secara sengaja untuk membantu pertumbuhan profesional guru. Lebih spesifik, dimaksudkan untuk meningkatkan dan mengembangkan kompetensi pedagogis, kepribadian, profesional, dan sosial bahkan dapat dilakukan sebagai wahana promosi bagi guru.

3. Pengembangan kompetensi pada guru sekolah dasar negeri di tempat UPTD kecamatan dalam kabupaten/kota secara umum belum merata di semua guru baik guru kelas, maupun guru mata pelajaran.

Hal yang sama berlaku juga pada Sekolah Menengah Pertama Negeri, maupun Sekolah Menengah Atas Negeri. Dari sejumlah guru mata pelajaran yang telah diikutkan ke pendidikan demi peningkatan kompetensi guru dan teknis ternyata belum berjalan secara maksimal artinya program kegiatan ini belum mereta diikuti oleh guru di masing-masing sekolah. Kebutuhan tenaga guru sekolah dasar negeri masih terjadi kesenjangan kelebihan dan kekurangan di beberapa sekolah. Persebaran guru kelas/wali kelas belum merata di sejumlah sekolah termasuk guru mata pelajaran umum, guru penjaskes dan guru mata pelajaran pendidikan agama. Demikian juga terjadi pada sekolah menengah pertama negeri dan sekolah menengah atas negeri.

Dengan demikian maka pemenuhan kebutuhan tenaga guru,kompetensi guru, pengembangan kompetensi guru/pendidikan dan latihan, serta persebaran kebutuhan tenaga guru pendidikan agama, guru oalahraga, guru kelas, maupun guru mata pelajaran pada sekolah dasar negeri, sekolah menengah pertama negeri, maupun sekolah menengah atas negeri yang telah dilaksanakan oleh Dinas Pendidikan Kabupaten Halmahera Timur belum maksimal.

\section{DAFTAR PUSTAKA}

Basuki Wibawa. (2005). Adiministrasi dan Supervisi Pendidikan. Yogyakarta: FIP IKIP Yogyakarta.

Budiningsih, (2005). Guru Sebagai Profesi. Bandung: Alfabeta.

Burhanudin, (1999). Analisisi AdministrasiManajemen \& Kepemimpinan Pendidikan.Jakarta: Bumi Aksara.

Danim, D. (2007). Inofasi Pendidikan Dalam Upaya Peningkatan Profesionalisme Tenaga Kependidikan. Jakarta: Pustaka Setia.

Dariyanto, (2008). Evaluasi Pendidikan. Jakarta: Rineka Cipta.

Engkoswara, (2004). Penerapan Sistem Guru Bidang Studi di Sekolah Dasar. Jakarta: Bina Prinido Aksara.

Hasibuan, Malayu SP. (2011) Manajemen Sumber Daya Manusia, Jakarta: Bumi Aksara. 
Subhan Hayun \& Rustam Hasyim. 2018. teachers' distribution, the developing teacher's competence

Handoko, T. Hani. (2009). Manajemen Personalia dan Sumber Daya Manusia. Yogyakarta: BPFE.

Handari Nawawi. (2008). Manajemen Strategik. Yogyakarta: Gadjah Mada University Press.

Kaswan, (2011). Pelatihan dan Pengembangan untuk Meningkatkan Kinerja SDM. Bandung: Alfabeta.

Kunandar (2007). Guru Profesional, Imlementasi KTSP dan Sukses Dalam Sertifikasi Guru. Jakarta: Rajawali Pers.

Mulyasa. (2010), Menjadi Guru Profesional, Menciptakan Pembelajaran Kreatif dan Menyenangkan. Bandung: Remaja Rosdakarya.

Margono. (2005). Metodologi Penelitian Pendidikan. Jakarta: Rineka Cipta

Sugiyono. (2010). Metode Penelitian Administrasi, Bandung:Alfabeta.

Suharsimi Arikunto \& Lia Yuliana. (2012). Manajemen Pendidikan. Yogyakarta: Aditya Media.

Syaiful Sagala. (2010). Manajemen Strategik Dalam Peningkatan Mutu Pendidikan. Bandung. Alfabeta.

Uzer Usman. Moh. 2010. Menjadi Guru Profesional.Bandung: Remaja Rosdakarya.

Usman Husaini. (2010). Menajemen Teori, Praktik, dan Riset Pendidikan.Jakarta: Bumi Aksara.

Zamroni (2007). Penilaian Hasil Proses Belajar Mengajar. Bandung: Remaja Rosdakarya.

Peraturan Perundangan

- $\quad$ Sumber data: Kependudukan dan Pencatat Sipil Kabupaten Halmahera Timur tahun 2012

- Sumber data: Dinas Pendidikan Pemuda dan Olahraga Kabupaten Halmahera Timur tahun 2012

- $\quad$ Sumber data: UPTD Dinas Pendidikan Nasional Kabupaten Halmahera Timur tahun 2012

- $\quad$ Sumber data: BPS Kabupaten Halmahera Timur 2012 